\title{
Knowledge, Attitude and Practice of Primary Health Care Physicians about Adult Vaccination in Abha City, Saudi Arabia
}

\author{
TURKI A. AL-GHANEM, M.D.*; ABDULQADER A.T. SUMAYLI, M.D.* and OSSAMA A. MOSTAFA, M.D.** \\ Ministry of Health* and Family \& Community Medicine Department**, King Khalid College of Medicine, Saudi Arabia
}

\begin{abstract}
Background: Adult vaccination has gained as much attention as childhood vaccination nationwide and worldwide in recent years. Several studies have been performed with a variety of suggestions regarding adult vaccination.

Aim of Study: To assess knowledge, attitude and practices of physicians providing primary health care (PHC) regarding adult vaccination and their own vaccination coverage as well as to explore the possible reasons for low vaccination coverage.

Material and Methods: Following a cross-sectional research design, this study included 103 PHC physicians in Abha City. Based on a similar previous study, a selfadministered questionnaire was adopted for data collection.

Results: Only $6 \%$ of PHC physicians had good knowledge, while $41 \%$ had positive attitude toward adult vaccination, while $10 \%$ had negative attitude. Most PHC physicians (70\%) had poor practice regarding adult vaccination, while only $10 \%$ had good practice. PHC physicians' knowledge was significantly better among older and non-Saudi physicians ( $p<0.001$ and $p=0.001$, respectively). PHC physicians' positive attitude toward adult vaccination was significantly higher among female participants ( $p=0.013)$, non-Saudi physicians $(p=0.004)$ and those with experience in PHC more than 10 years $(p=0.044)$. PHC physicians' good practice regarding adult vaccination was significantly higher among older physicians and among those with experience in PHC more than 10 years $(p=0.004)$. The most frequently stated reasons for low adult vaccination coverage were "Lack of coordinated immunization programs for adults" (63.1\%), "Physicians do not inform patients about adult vaccination because they do not have enough time" (61.2\%) and "Lack of availability of up-to-date records and recording systems" (55.3\%).
\end{abstract}

Conclusions: Knowledge of PHC physicians regarding adult vaccination is suboptimal although most of them do not have negative attitude toward adult vaccination. Their practice regarding adult vaccination is mostly poor. There are several identified obstacles against implementing vaccination of adults.

Recommendations: To construct a national guideline for adult vaccination. To organize continuing medical education courses on adult vaccination for PHC physicians. Obstacles against adult vaccination should be further studied and overcome.

Correspondence to: Dr. Turki A. Al-Ghanem,

Ministry of Health, Saudi Arabia
Key Words: Vaccination - Primary care - Knowledge Attitude.

\section{Introduction}

ADULT vaccination has gained as much attention as childhood vaccination nationwide and worldwide in recent years. Several studies have been performed with a variety of suggestions regarding adult vaccination [1-4]. But still, vaccination is not seen as a part of adult health care services, and adult vaccination programs are not as effective and as approachable as they are in childhood $[4,5]$. Lack of knowledge in physicians and in society, preoccupations concerning the efficacy and side effects of vaccines, not being under the coverage of health insurance, the lack of a national health policy regarding adult vaccination and the economic cost that it brings to the government can all be considered as reasons for insufficient adult vaccination [6-8]

An estimated 50,000-90,000 Americans die of vaccine preventable diseases each year, the vast majority of these being adults. With the recent emergence of viral strains and bacterial organisms that have had more serious consequences in healthy young adults, routine vaccination of this population is a growing necessity. Furthermore, the healthcare cost of vaccine preventable diseases (VPDs) is substantial. For example, the yearly national economic burden of influenza disease is estimated to be $\$ 10.4$ billion in direct medical costs and a total economic burden of over $\$ 87$ billion [9]. If one takes into account the multiple other preventable diseases, the economic and health cost can be astronomical. The importance and urgency of this matter has become a major focus of both the Centers for Diseases Control and Prevention (CDC) and the Infectious Diseases Society of America. Increasing adult vaccination rates and awareness has become a public health priority. Because of the nature of transmissible diseases, immunization is 
important not only for an individual's health, but also for the health of the community at large [10]

In Saudi Arabia, until very recently vaccination has been considered as a special procedure for children, and apart from some exceptional cases and individual applications, adult vaccination has been neglected. Planning, coordination and continuity in administration are all very important issues in obtaining success [11]. Increasing the awareness of physicians, in other words, dealing with the lack of knowledge, which is accepted as one of the reasons for insufficient adult vaccination, and implementing them to give the necessary importance, will provide success in adult vaccination [12]. Physicians should evaluate the adults they see in hospitals or polyclinics, whether healthy or ill, regarding immunization against preventable diseases. They should not miss the opportunity of completing missing vaccines, they should inform the patients about the diseases and the importance of vaccination [12]

In recent years, new vaccines such as herpes zoster and human papillomavirus have become available for adults. Despite these advances, the vaccination rates of adults in Saudi Arabia are low, resulting in many adults remaining vulnerable to vaccine preventable diseases [11].

\section{Common reasons for incomplete immunization in} adulthood include [13]:

- Lack of recognition of the importance of adult immunization.

- Lack of recommendation from health care providers.

- Lack of health care provider knowledge about adult immunization and recommended vaccines.

- Misrepresentation/misunderstanding of the risks of vaccine and benefits of disease prevention in adults.

- Lack of understanding of vaccine safety and efficacy.

- Missed opportunities for vaccination in health care providers' offices, hospitals and nursing homes.

- Lack of publicly-funded vaccine and reimbursement to vaccine providers.

- Lack of coordinated immunization programs for adults.

- Lack of regulatory or legal requirements.

- Fear of injections.

- Lack of availability of up-to-date records and recording systems.
Vaccines that should be administered at risky situations have also been stated in this guideline. Physicians have a high probability of being exposed to these preventable diseases and the risk of infecting their patients is also high, this renders their vaccination coverage to be even more important. Under this condition, this study was carried out to establish the knowledge and attitude of family physicians offering primary health care (PHC), toward adult vaccination and their own vaccination coverage.

This study aimed to assess knowledge, attitude and practice of primary care physicians offering primary health care, toward adult vaccination and their own vaccination coverage as well as to identify reasons for low vaccination coverage.

\section{Material and Methods}

The study was conducted in Abha City, Asser Province, Saudi Arabia during January - April 2018. There are 47 PHC centers, with 128 physicians. [14].

A cross sectional research design was followed to include all PHC physicians in Abha City. A total of 103 PHC physicians agreed to participate (response rate $=80.5 \%$ ).

The researchers used a self-administered questionnaire in English Language, that was previously used in a similar study and proved to be valid and reliable [12]. In addition to the questions about the descriptive characteristics of participant physicians, their vaccination coverage, their relatives' vaccination coverage, which adult vaccines they knew, and their attitude towards suggesting them to their patients were all inquired. To establish which vaccines they would suggest, they were asked to write the vaccines in some given situations. The 2009 report from the Centers of Disease Control and Prevention (CDC) was taken into account in the preparation of the questions regarding risk factors and the age at which the vaccinations should be applied [4].

A pilot study was conducted on 10 family medicine residents in Aseer Program over one week. It helped in the adaptation of the study questionnaire. The results were not included in the main report.

For data collection, the researchers distributed the self-administered questionnaire during the working hours, with utmost care not to disturb the PHC physicians. The questionnaires sheets were collected on the same day. 
Collected data were verified by hand then were coded and entered into a personal computer. Statistical analysis was conducted using the Statistical Package of Social Sciences (IBM-SPSS version 25.0 for Windows, SPSS Inc., Chicago, IL, USA). Data were shown as frequency and percentage. For the comparison of categorical data, Chi-square test was applied. $p$-values less than 0.05 were considered as statistically significant.

\section{Results}

Table (1) shows that $34 \%$ of participants were less than 30 years old, $44.7 \%$ were $30-40$ years old and $21.4 \%$ were older than 40 years. About two thirds of participants (65\%) were males, $63.1 \%$ were Saudi. About two thirds of participants $(65 \%)$ were MBBS qualified, $19.4 \%$ had Diploma or Master degrees and $15.5 \%$ had $\mathrm{PhD}$ or equivalent. Almost half of participants (47.6\%) were general practitioners, $33 \%$ were residents, $17.5 \%$ were registrars/senior registrars, while $1.9 \%$ were consultants. Participants experience in PHC practice was less than 5 years among $46.6 \%, 5-10$ years among $34 \%$ and more than 10 years among $19.4 \%$.

Table (1): Personal characteristics of study sample.

\begin{tabular}{|c|c|c|}
\hline Personal characteristics & No. & $\%$ \\
\hline \multicolumn{3}{|l|}{ Age group: } \\
\hline$\cdot<30$ years & 35 & 34.0 \\
\hline - $30-40$ years & 46 & 44.7 \\
\hline - $>40$ years & 22 & 21.4 \\
\hline \multicolumn{3}{|l|}{ Gender: } \\
\hline$\bullet$ Male & 67 & 65.0 \\
\hline - Female & 36 & 35.0 \\
\hline \multicolumn{3}{|l|}{ Nationality: } \\
\hline - Saudi & 65 & 63.1 \\
\hline - Non-Saudi & 38 & 36.9 \\
\hline \multicolumn{3}{|l|}{ Qualification: } \\
\hline$\cdot \mathrm{MBBS}$ & 67 & 65.0 \\
\hline •Diploma/Master & 20 & 19.4 \\
\hline - PhD/Board/Doctorate & 16 & 15.5 \\
\hline \multicolumn{3}{|l|}{ Position: } \\
\hline - General practitioner & 49 & 47.6 \\
\hline • Resident & 34 & 33.0 \\
\hline - Registrar/Senior registrar & 18 & 17.5 \\
\hline - Consultant & 2 & 1.9 \\
\hline \multicolumn{3}{|l|}{ Experience in PHC practice: } \\
\hline$\bullet<5$ years & 48 & 46.6 \\
\hline - 5-10 years & 35 & 34.0 \\
\hline$\bullet>10$ years & 20 & 19.4 \\
\hline
\end{tabular}

Table (2) shows that primary health care physicians' knowledge regarding adult vaccination differed significantly according to their age with highest proportion of those with poor knowledge among the youngest age group and the lowest proportion of those with poor knowledge among older age groups $(p<0.001)$. Saudi physicians had significantly higher proportion of poor knowledge than non-Saudi physicians ( $80 \%$ vs. $60.5 \%$, respectively, $p=0.001$ ). However, primary health care physicians' knowledge grades did not differ according to their gender, qualification, position or experience in primary health care practice.

Table (2): Primary health care physicians' knowledge grades regarding adult vaccination according to their personal characteristics.

\begin{tabular}{|c|c|c|c|c|c|c|c|}
\hline \multirow{2}{*}{$\begin{array}{l}\text { Personal } \\
\text { characteristics }\end{array}$} & & & $\begin{array}{r}\mathrm{Moc} \\
\quad(\mathrm{n}=\end{array}$ & & & & \multirow{2}{*}{$\begin{array}{c}p- \\
\text { value }\end{array}$} \\
\hline & No. & $\%$ & No. & $\%$ & No. & $\%$ & \\
\hline
\end{tabular}

\begin{tabular}{|c|c|c|c|c|c|c|c|}
\hline $\begin{array}{c}\text { Age group: } \\
\quad<<30 \text { years } \\
\quad \cdot 30-40 \text { years } \\
\quad \cdot>40 \text { years }\end{array}$ & $\begin{array}{l}29 \\
36 \\
10\end{array}$ & $\begin{array}{l}82.9 \\
78.3 \\
45.5\end{array}$ & $\begin{array}{l}2 \\
10 \\
10\end{array}$ & $\begin{array}{l}5.7 \\
21.7 \\
45.5\end{array}$ & $\begin{array}{l}4 \\
0 \\
2\end{array}$ & $\begin{array}{l}11.4 \\
0.0 \\
9.1\end{array}$ & $<0.001$ \\
\hline $\begin{array}{l}\text { Gender: } \\
\quad \text { - Male } \\
\text { - Female }\end{array}$ & $\begin{array}{l}47 \\
28\end{array}$ & $\begin{array}{l}70.1 \\
77.8\end{array}$ & $\begin{array}{l}14 \\
8\end{array}$ & $\begin{array}{l}20.9 \\
22.2\end{array}$ & $\begin{array}{l}6 \\
0\end{array}$ & $\begin{array}{l}9.0 \\
0.0\end{array}$ & 0.180 \\
\hline $\begin{array}{l}\text { Nationality: } \\
\text { - Saudi } \\
\text { - Non-Saudi }\end{array}$ & $\begin{array}{l}52 \\
23\end{array}$ & $\begin{array}{l}80.0 \\
60.5\end{array}$ & $\begin{array}{l}7 \\
15\end{array}$ & $\begin{array}{l}10.8 \\
39.5\end{array}$ & $\begin{array}{l}6 \\
0\end{array}$ & $\begin{array}{l}9.2 \\
0.0\end{array}$ & 0.001 \\
\hline $\begin{array}{l}\text { Qualification: } \\
\text { - MBBS } \\
\text { - Diploma/Master } \\
\text { - PhD/Board/ } \\
\text { Doctorate }\end{array}$ & $\begin{array}{l}53 \\
12 \\
10\end{array}$ & $\begin{array}{l}79.1 \\
60.0 \\
62.5\end{array}$ & $\begin{array}{l}12 \\
6 \\
4\end{array}$ & $\begin{array}{l}17.9 \\
30.0 \\
25.0\end{array}$ & $\begin{array}{l}2 \\
2 \\
2\end{array}$ & $\begin{array}{l}3.0 \\
10.0 \\
12.5\end{array}$ & 0.290 \\
\hline $\begin{array}{l}\text { Position: } \\
\text { - Resident } \\
\text { - General } \\
\text { practitioner } \\
\text { - Registrar/ } \\
\text { Senior registrar }\end{array}$ & $\begin{array}{l}24 \\
35\end{array}$ & $\begin{array}{l}70.6 \\
71.4 \\
100.0\end{array}$ & $\begin{array}{l}6 \\
12\end{array}$ & $\begin{array}{l}17.6 \\
24.5\end{array}$ & $\begin{array}{l}4 \\
2\end{array}$ & $\begin{array}{l}11.8 \\
4.1 \\
0.0\end{array}$ & 0.588 \\
\hline $\begin{array}{l}\text { Experience in } P H C \\
\text { practice: } \\
\bullet<5 \text { years } \\
\cdot 5-10 \text { years } \\
\bullet>10 \text { years }\end{array}$ & $\begin{array}{l}38 \\
25 \\
12\end{array}$ & $\begin{array}{l}79.2 \\
71.4 \\
60.0\end{array}$ & $\begin{array}{l}6 \\
8 \\
8\end{array}$ & $\begin{array}{l}12.5 \\
22.9 \\
40.0\end{array}$ & $\begin{array}{l}4 \\
2 \\
0\end{array}$ & $\begin{array}{l}8.3 \\
5.7 \\
0.0\end{array}$ & 0.113 \\
\hline
\end{tabular}

Table (3) shows that primary health care physicians' positive attitude toward adult vaccination was significantly higher among female participants ( $p=0.013)$, among Non-Saudi physicians $(p=0.004)$, among registrars and senior registrars $(p=0.001)$ and among those with experience in primary health care more than 10 years $(p=0.044)$. However, primary health care physicians' attitude grades did not differ according to their age or qualification.

Table (4) shows that primary health care physicians' good practice regarding adult vaccination was significantly higher among participants older than 40 years $(p<0.001)$, among MBBS qualified physicians $(p=0.018)$, and among those with experience in primary health care more than 10 years $(p=0.004)$. However, primary health care physicians' practice grades did not differ according to their gender, nationality or position. 
Table (3): Primary health care physicians' attitude grades regarding adult vaccination according to their personal characteristics.

\begin{tabular}{|c|c|c|c|c|c|c|c|}
\hline \multirow{2}{*}{$\begin{array}{l}\text { Personal } \\
\text { characteristics }\end{array}$} & \multicolumn{2}{|c|}{$\begin{array}{c}\text { Negative } \\
(\mathrm{n}=10)\end{array}$} & \multicolumn{2}{|c|}{$\begin{array}{c}\text { Neutral } \\
(n=51)\end{array}$} & \multicolumn{2}{|c|}{$\begin{array}{c}\text { Positive } \\
(\mathrm{n}=42)\end{array}$} & \multirow{2}{*}{$\begin{array}{c}p \\
\text { value }\end{array}$} \\
\hline & No. & $\%$ & No. & $\%$ & No. & $\%$ & \\
\hline $\begin{array}{l}\text { Age group: } \\
\text { - <30 years } \\
\cdot \text { - 30-40 years } \\
\cdot>40 \text { years }\end{array}$ & $\begin{array}{l}4 \\
6 \\
0\end{array}$ & $\begin{array}{l}11.4 \\
13.0 \\
0.0\end{array}$ & $\begin{array}{l}19 \\
22 \\
10\end{array}$ & $\begin{array}{l}54.3 \\
47.8 \\
45.5\end{array}$ & $\begin{array}{l}12 \\
18 \\
12\end{array}$ & $\begin{array}{l}34.3 \\
39.1 \\
54.5\end{array}$ & 0.349 \\
\hline $\begin{array}{l}\text { Gender: } \\
\text { - Male } \\
\text { - Female }\end{array}$ & $\begin{array}{l}10 \\
0\end{array}$ & $\begin{array}{l}14.9 \\
0.0\end{array}$ & $\begin{array}{l}35 \\
16\end{array}$ & $\begin{array}{l}52.2 \\
44.4\end{array}$ & $\begin{array}{l}22 \\
20\end{array}$ & $\begin{array}{l}32.8 \\
55.6\end{array}$ & 0.013 \\
\hline $\begin{array}{l}\text { Nationality } \\
\text { - Saudi } \\
\text { - Non-Saudi }\end{array}$ & $\begin{array}{l}9 \\
1\end{array}$ & $\begin{array}{l}13.8 \\
2.6\end{array}$ & $\begin{array}{l}37 \\
14\end{array}$ & $\begin{array}{l}56.9 \\
36.8\end{array}$ & $\begin{array}{l}19 \\
23\end{array}$ & $\begin{array}{l}29.2 \\
60.5\end{array}$ & 0.004 \\
\hline $\begin{array}{l}\text { Qualification: } \\
\text { - MBBS } \\
\text { - Diploma/ } \\
\text { Master } \\
\text { - PhD/Board/ } \\
\text { Doctorate }\end{array}$ & $\begin{array}{l}8 \\
0\end{array}$ & $\begin{array}{l}11.9 \\
0.0 \\
12.5\end{array}$ & $\begin{array}{l}31 \\
12\end{array}$ & $\begin{array}{l}46.3 \\
60.0\end{array}$ & $\begin{array}{l}28 \\
8\end{array}$ & $\begin{array}{l}41.8 \\
40.0 \\
37.5\end{array}$ & 0.547 \\
\hline $\begin{array}{l}\text { Position: } \\
\text { - Resident } \\
\text { - Registrar/ } \\
\text { Senior registrar } \\
\text { - Genera } \\
\text { practitioner } \\
\text { - Consultant }\end{array}$ & $\begin{array}{l}2 \\
0 \\
6\end{array}$ & $\begin{array}{l}5.9 \\
0.0\end{array}$ & $\begin{array}{l}20 \\
8\end{array}$ & $\begin{array}{l}58.8 \\
44.4\end{array}$ & $\begin{array}{l}12 \\
10\end{array}$ & $\begin{array}{l}35.3 \\
55.6\end{array}$ & 0.001 \\
\hline $\begin{array}{l}\text { Experience in } \mathrm{PHC} \\
\text { practice: } \\
\quad \bullet<5 \text { years } \\
\cdot \text { - 5-10 years } \\
\cdot>10 \text { years }\end{array}$ & $\begin{array}{l}6 \\
4 \\
0\end{array}$ & $\begin{array}{l}12.5 \\
11.4 \\
0.0\end{array}$ & $\begin{array}{l}27 \\
18 \\
6\end{array}$ & $\begin{array}{l}56.3 \\
51.4 \\
30.0\end{array}$ & $\begin{array}{l}15 \\
13 \\
14\end{array}$ & $\begin{array}{l}31.3 \\
37.1 \\
70.0\end{array}$ & 0.044 \\
\hline
\end{tabular}

Table (4): Primary health care physicians' practice grades regarding adult vaccination according to their personal characteristics.

\begin{tabular}{|c|c|c|c|c|c|c|c|}
\hline \multirow{2}{*}{$\begin{array}{l}\text { Personal } \\
\text { characteristics }\end{array}$} & \multicolumn{2}{|c|}{$\begin{array}{l}\text { Poor } \\
(\mathrm{n}=72)\end{array}$} & \multicolumn{2}{|c|}{$\begin{array}{c}\text { Moderate } \\
(\mathrm{n}=21)\end{array}$} & \multicolumn{2}{|c|}{$\begin{array}{c}\text { Good } \\
(\mathrm{n}=10)\end{array}$} & \multirow{2}{*}{$\begin{array}{c}p- \\
\text { value }\end{array}$} \\
\hline & No. & $\%$ & No. & $\%$ & No. & $\%$ & \\
\hline \multicolumn{8}{|l|}{ Age group: } \\
\hline$\bullet<30$ years & 27 & 77.1 & 6 & 17.1 & 2 & 5.7 & $<0.001$ \\
\hline - $30-40$ years & 39 & 84.8 & 5 & 10.9 & 2 & 4.3 & \\
\hline$\cdot>40$ years & 6 & 27.3 & 10 & 45.5 & 6 & 27.3 & \\
\hline \multicolumn{8}{|l|}{ Gender: } \\
\hline$\bullet$ Male & 49 & 73.1 & 14 & 20.9 & 4 & 6.0 & 0.215 \\
\hline - Female & 23 & 63.9 & 7 & 19.4 & 6 & 16.7 & \\
\hline \multicolumn{8}{|l|}{ Nationality: } \\
\hline - Saudi & 50 & 76.9 & 11 & 16.9 & 4 & 6.2 & 0.102 \\
\hline - Non-Saudi & 22 & 57.9 & 10 & 26.3 & 6 & 15.8 & \\
\hline \multicolumn{8}{|l|}{ Qualification: } \\
\hline - MBBS & 49 & 73.1 & 10 & 14.9 & 8 & 11.9 & 0.018 \\
\hline - Diploma/Master & r 9 & 45.0 & 9 & 45.0 & 2 & 10.0 & \\
\hline $\begin{array}{l}\text { - PhD/Board/ } \\
\text { Doctorate }\end{array}$ & 14 & 87.5 & 2 & 12.5 & 0 & 0.0 & \\
\hline \multicolumn{8}{|l|}{ Position: } \\
\hline • Resident & 22 & 64.7 & 6 & 17.6 & 6 & 17.6 & 0.457 \\
\hline $\begin{array}{l}\text { - Registrar/ } \\
\text { Senior registrar }\end{array}$ & 13 & 72.2 & 5 & 27.8 & 0 & 0.0 & \\
\hline $\begin{array}{l}\text { - General } \\
\text { practitioner }\end{array}$ & 35 & 71.4 & 10 & 20.4 & 4 & 8.2 & \\
\hline • Consultant & 2 & 100.0 & 0 & 0.0 & 0 & 0.0 & \\
\hline \multicolumn{8}{|l|}{ Experience in } \\
\hline \multicolumn{8}{|l|}{ PHC practice: } \\
\hline - 5-10 years & 28 & 80.0 & 7 & & 0 & 0.0 & \\
\hline$\cdot>10$ years & 10 & 50.0 & 4 & 20.0 & 6 & 30.0 & \\
\hline
\end{tabular}

Table (5) shows that the most frequently stated reasons for low adult vaccination coverage were "Lack of coordinated immunization programs for adults" (63.1\%), "Physicians do not inform patients about adult vaccination because they do not have enough time" (61.2\%) and "Lack of availability of up-to-date records and recording systems" $(55.3 \%)$

Table (5): Opinions of primary health care physicians regarding the possible causes of low adult vaccination rates.

\begin{tabular}{|c|c|c|c|c|c|c|}
\hline \multirow{2}{*}{ Opinion } & \multicolumn{2}{|c|}{ Agree } & \multicolumn{2}{|c|}{ Neutral } & \multicolumn{2}{|c|}{ Disagree } \\
\hline & No. & $\%$ & No. & $\%$ & No. & $\%$ \\
\hline $\begin{array}{l}\text { Physicians do not inform } \\
\text { patients about adult } \\
\text { vaccination because they } \\
\text { do not have enough } \\
\text { time. }\end{array}$ & 63 & 61.2 & 16 & 15.5 & 24 & 23.3 \\
\hline $\begin{array}{l}\text { Physicians prioritize } \\
\text { treatment over } \\
\text { prevention. }\end{array}$ & 51 & 49.5 & 30 & 29.1 & 22 & 21.4 \\
\hline $\begin{array}{l}\text { Patients refuse } \\
\text { vaccination. }\end{array}$ & 24 & 23.3 & 33 & 32.0 & 46 & 44.7 \\
\hline $\begin{array}{l}\text { Health care providers lack } \\
\text { knowledge about adult } \\
\text { immunization and } \\
\text { recommended vaccines. }\end{array}$ & 42 & 40.8 & 36 & 35.0 & 25 & 24.3 \\
\hline $\begin{array}{l}\text { Physicians' disbelief in } \\
\text { adult vaccination. }\end{array}$ & 10 & 9.7 & 18 & 17.5 & 75 & 72.8 \\
\hline $\begin{array}{l}\text { Misrepresentation/misun } \\
\text { derstanding of the risks } \\
\text { of vaccine and benefits } \\
\text { of disease prevention in } \\
\text { adults. }\end{array}$ & 21 & 20.4 & 50 & 48.5 & 32 & 31.1 \\
\hline $\begin{array}{l}\text { Lack of understanding of } \\
\text { vaccine safety and } \\
\text { efficacy. }\end{array}$ & 18 & 17.5 & 45 & 43.7 & 40 & 38.8 \\
\hline $\begin{array}{l}\text { Missed opportunities for } \\
\text { vaccination in health } \\
\text { care providers' offices, } \\
\text { hospitals and nursing } \\
\text { homes. }\end{array}$ & 46 & 44.7 & 33 & 32.0 & 24 & 23.3 \\
\hline $\begin{array}{l}\text { Lack of publicly-funded } \\
\text { vaccine and } \\
\text { reimbursement to } \\
\text { vaccine providers. }\end{array}$ & 35 & 34.0 & 50 & 48.5 & 18 & 17.5 \\
\hline $\begin{array}{l}\text { Lack of coordinated } \\
\text { immunization programs } \\
\text { for adults. }\end{array}$ & 65 & 63.1 & 26 & 25.2 & 12 & 11.7 \\
\hline $\begin{array}{l}\text { Lack of regulatory or legal } \\
\text { requirements. }\end{array}$ & 35 & 34.0 & 40 & 38.8 & 28 & 27.2 \\
\hline Fear of injections. & 22 & 21.4 & 41 & 39.8 & 40 & 38.8 \\
\hline $\begin{array}{l}\text { Lack of availability of up- } \\
\text { to-date records and } \\
\text { recording systems. }\end{array}$ & 57 & 55.3 & 32 & 31.1 & 14 & 13.6 \\
\hline
\end{tabular}




\section{Discussion}

Globally, adult vaccination has recently gained as much attention as childhood vaccination worldwide [12]. However, vaccination of adults has not been seen as a part of adult health care services, and adult vaccination programs are not as effective and as approachable as they are in childhood [5] .

Results of this study showed the variability in qualifications and positions among participant primary health care physicians. About two thirds of participants were general practitioners with MBBS Degree, while one third of them had Diploma, Master, $\mathrm{PhD}$ or equivalent. Almost half of participants were general practitioners, one third were residents, and the rest were registrars/senior registrars or consultants.

This finding is in agreement with that of that of Bovier et al., [5] who noted the wide variability in primary care physicians' qualifications and specialties in Geneva, Switzerland, where almost half of physicians were general practitioners and the other half were general internists or other specialties.

Results of the present study revealed that, regarding primary health care physicians' knowledge about adult vaccination, only $6 \%$ had good knowledge, $21 \%$ had moderate knowledge, while $73 \%$ had poor knowledge. Regarding vaccinating adults in high risk groups, participants' most correct responses were related to influenza vaccine followed by pneumococcal vaccines, while the knowledge of most participants about all other vaccines were deficient. Regarding their knowledge about vaccines administered to adults in some disease groups, the highest correct responses were related to influenza and pneumococcal vaccines, while the knowledge of most participants about all other vaccines were deficient.

In USA, Tan et al., [15] reported that primary care physicians had low knowledge regarding adult vaccination.

Hurley et al., [16] explained the variability in primary health care physicians' knowledge regarding different adult vaccines by that, in primary care practice, an environment with lower perceived priority of certain vaccines could have implications for knowledge and vaccine delivery. Several factors contribute to primary health care physicians' perceptions that some vaccines are less important than other preventive services, including evidence supporting the use of the preventive service, access to the service, patient demand for the service, physician experience treating certain diseases, clarity of the guideline recommending the service, and whether or not the service is tracked as a performance measure for the practice. The poor physicians' knowledge regarding some vaccines, e.g., tetanus, compared with better knowledge regarding other vaccines, e.g., influenza and pneumococcal vaccines, may reflect the difficulty some physicians have in providing these vaccines to the adult population.

The Centers for Disease Control and Prevention [17] reported that, the adult vaccination schedule is complex since several vaccine recommendations are risk-based or require knowledge of vaccination history, which is often not available. Most physicians agreed that the age-based and medical condition-based indications for vaccination were difficult to follow.

These findings are in agreement with those of MacDougall et al., [18] in Canada, who noted that despite guidelines for adult vaccination, there are substantial gaps in knowledge among healthcare providers.

Findings of the present study showed that $41 \%$ had positive attitude toward adult vaccination. Most primary health care physicians agreed that adult vaccination a protective modality, that pregnant women should be asked about their vaccination coverage, that there is a need to ask patients at risk about their vaccination coverage and that it is important to ask elderly patients about their vaccination coverage. However, about one fourth of participants think that there is no need to establish antibody levels before hepatitis B vaccination and another one fourth of them think that their knowledge about adult vaccination is insufficient.

These findings are in accordance with those of Baykan et al., [12] who found that $83 \%$ of primary health care physicians believe that vaccinating adults is a modality of protection, $49.6 \%$ agreed to question pregnant women about their vaccination coverage, $68.8 \%$ agreed that there is a need to ask adult patients at risk about their vaccination coverage, but $18.4 \%$ agreed to ask elderly patients (aged 65 years or more) about their vaccination coverage, $12.4 \%$ stated that there is no need to establish antibody levels before hepatitis B vaccination and $23.4 \%$ of primary health care physicians find their knowledge about adult vaccination as insufficient.

MacDougall et al., [18] found that about half of physicians have positive attitudes toward adult vaccination, where $46.9 \%$ of physicians believed 
that vaccines are more important for children than adults, $54.7 \%$ agreed that it is difficult to keep up with vaccination recommendations for adults.

Findings of the present study showed that most primary health care physicians had poor practice regarding adult vaccination, while only $10 \%$ had good practice. About three fourths of primary health care physicians received influenza and hepatitis B vaccines, while $40.8 \%$ received tetanus vaccine, $21.4 \%$ received the pneumococcal vaccine and $13.6 \%$ received the HPV vaccine. In addition, about half of participants vaccinated their first-degree relatives against influenza, while other vaccines were less frequently applied. Moreover, most participants recommended the influenza vaccines to their patients, while other vaccines were less frequently recommended.

Pickering et al., [19] stated that the risk of health personnel of being exposed to diseases preventable by vaccination and of infecting their patients is substantially high. Health personnel should get a repeat dose of tetanus. All people dealing with blood and blood products should be vaccinated against hepatitis B, and every health personnel should get an influenza vaccination. Apart from these, some other vaccinations are administered in special situations.

Vaccination against influenza was received by most participant primary care physicians in the present study $(75.7 \%)$. Lower rates have been reported by Baykan et al., [12] in Turkey (58.5\%). Moreover, vaccination rates of physicians' firstdegree relatives were also low.

It is to be noted that influenza vaccination has been suggested to the health personnel by CDC, since 1980's. The mainstay of this suggestion is that sick health personnel pose the risk of infecting patients at work, and in places with non-vaccinated health personnel, hospital-borne influenza epidemics can be seen [20-22]

Szucs et al., [23] added that vaccination of health personnel decreases patient morbidity and mortality and days out of work, and provides economic contribution to healthcare organizations. Nevertheless, several studies in Australia, Italy and USA indicated that the influenza vaccination rates among health personnel was below 50\% [24-25].

Vaccination against hepatitis B was received by most participant primary care physicians in the present study (75.7\%), while $40.8 \%$ had their firstdegree relatives being vaccinated, while $61.2 \%$ of participants suggested it to their patients.
Aka and Dündar [26] stated that blood-borne infectious diseases pose an occupational hazard for health workers. In a university hospital, they reported that $37 \%$ of health personnel that had the risk of contact with patients' blood were vaccinated against hepatitis B.

In Turkey, Demir et al., [27] reported that vaccination rate against hepatitis B was $55.8 \%$ while Uzun et al., [28] reported a vaccination rate of $88.7 \%$ among residents of a university hospital, while Baykan et al., [12] reported that $67.0 \%$ of physicians were vaccinated against hepatitis B. In studies from France and USA the vaccination rates against hepatitis B were around 80\%-90\% [29,30]

In USA, Campos-Outcalt et al., [31] noted that $80 \%$ of family physicians reported providing most routinely recommended adult vaccines at their practice primary health care sites.

The present study showed that primary health care physicians' knowledge regarding adult vaccination differed significantly according to their age with highest proportion of those with poor knowledge among the youngest age group. Saudi physicians had significantly higher proportion of poor knowledge than non-Saudi physicians. Moreover, physicians' positive attitude toward adult vaccination was significantly higher among female participants, among non-Saudi physicians, among registrars and senior registrars and among those with experience in primary health care more than 10 years. In addition, physicians' good practice regarding adult vaccination was significantly higher among participants older than 40 years, among MBBS qualified physicians, and among those with experience in primary health care more than 10 years.

Perhaps better knowledge regarding adult vaccination among older physicians can be expected. However, a higher proportion of poor knowledge among Saudi physicians may be explained by the fact that in Saudi Arabia, the employment of nonSaudi physicians follows strict criteria to employ only the best knowledgeable physicians. In addition, non-Saudi physicians have to follow the guidelines very carefully to avoid termination of their contracts. All these points do not perfectly apply to Saudi primary health care physicians. Hence, the significantly poorer knowledge among Saudi physicians.

Hurley et al., [24] stated that primary health care providers had positive attitude toward adult vaccination, which was significantly higher among females and those with more experience in medical practice. 
Abramson and Levi [6] and Baykan et al., [12] found that vaccination practices for adults were higher in female physicians compared to male physicians, but with no significant differences.

Results of the present study showed that the most frequently stated reasons for low adult vaccination coverage were "Lack of coordinated immunization programs for adults", "Physicians do not inform patients about adult vaccination because they do not have enough time" and "Lack of availability of up-to-date records and recording systems".

Several studies reported reasons for low rates of adult vaccination. Stated reasons comprised lack of knowledge among primary care physicians, preoccupations concerning the efficacy and side effects of vaccines, not being under the coverage of health insurance, the lack of a national health policy regarding adult vaccination and the economic cost that it brings to the government can all be considered as reasons for insufficient adult vaccination $[6,32,33]$.

Bovier et al., [5] stated that the most important reason behind missed opportunities for adult vaccination is the lack of the motivation physicians should provide to their patients. Johnson et al., [34] reported that the reasons for low vaccination rates were; the refusal of patient to come in for controls, there being no reminding warning system for adult vaccination, and refusal of vaccination itself. Baykan et al., [12] found that the first three factors for low adult vaccination rates were lack of time, physicians prioritizing treatment modalities, and patients' refusal of vaccination. Nevertheless, the main factor for low adult vaccination rates remains to be the physicians' lack of knowledge.

The National Foundation for Infectious Diseases [35] noted that adult immunization schedule may not be well understood by primary health care providers. The first step toward increasing adult vaccination rates is to communicate who should be vaccinated and when. Vaccination barriers exist among healthcare providers and delivery systems.

\section{Conclusions:}

Based on results of the present study, it can be concluded that knowledge of PHC physicians regarding adult vaccination is suboptimal, although most of them do not have negative attitude toward adult vaccination, while their practices regarding adult vaccination is mostly poor. PHC physicians' knowledge regarding adult vaccination is less among younger and Saudi physicians, and their attitude is more positive among females, nonSaudis and those with more experience in primary health care practice, while their practices regarding adult vaccination are better among older physicians with more experience in primary care practice. PHC physicians' most frequently stated reasons for low adult vaccination coverage are "Lack of coordinated immunization programs for adults", "Physicians do not inform patients about adult vaccination because they do not have enough time" and "Lack of availability of up-to-date records and recording systems".

\section{Recommendations:}

Based on results of this study, it is recommended to raise the awareness of PHC providers regarding adult vaccination. There is a need to construct a Saudi national guideline for adult vaccination that should comprise coordinated immunization programs for adults with detailed indications and target groups for each vaccine. The Saudi Ministry of Health should plan and organize continuing medical education courses on adult vaccination for primary health care physicians. Further studies are need to explore and overcome obstacles against adult vaccination.

\section{References}

1- JACKSON M.L., CHUNG J.R., JACKSON L.A., PHILLIPS C.H., BENOIT J., MONTO A.S., et al.: Influenza Vaccine Effectiveness in the United States during the 2015-2016 Season. N. Engl. J. Med., 377 (6): 534-543, 2017.

2- MARIN M., MARLOW M., MOORE K.L. and PATEL M.: Recommendation of the Advisory Committee on Immunization Practices for Use of a Third Dose of Mumps Virus-Containing Vaccine in Persons at Increased Risk for Mumps During an Outbreak. MMWR Morb Mortal Wkly Rep., 67 (1): 33-38. 2018.

3- SHA B.E.: Adult Immunization Update. JAMA, 322 (11): 1096-1097, 2019.

4- KIM D.K. and HUNTER P.: Recommended Adult Immunization Schedule, United States, 2019. Ann. Intern. Med. 170: 182-92, 2019.

5- BOVIER P.A., CHAMOT E. and BOUVIER G.M.: Importance of patients' perceptions and general practitioners' recommendations in understanding missed opportunities for immunizations in Swiss adults. Vaccine, 19 (32): 4760-4767, 2001

6- ABRAMSON Z.H. and LEVI O.: Influenza vaccination among primary healthcare workers. Vaccine, 26 (20): 2482-2489, 2008.

7- MÜLER D. and SZUCS T.D.: Influenza vaccination coverage rates in 5 European countries: A populationbased cross-sectional analysis of the seasons 02/03, 03/04 and 04/05. Infection, 35 (5): 308-319, 2007.

8- BLANK P.R., SCHWENKGLENKS M. and SZUCS T.D.: Influenza vaccination coverage rates in five European 
countries during Season 2006/07 and Trends over Six Consecutive Seasons. BMC Public Health, 8 (271): 1-13, 2008.

9- MOLINARI N.A., ORTEGA-SANCHEZ I.R., MESSONNIER M.L., THOMPSON W.W., WORTLEY P.M., et al.: The annual impact of seasonal influenza in the US: Measuring disease burden and costs. Vaccine, 25: 5086-5096, 2007.

10- BHATTACHARYA L.K., GERBIE M.V. and TAN T.Q.: Knowledge and Utilization of Recommended Preventative Vaccines among Young Adults. J. Vaccines, 4: 3, 2013.

11- AL-AHMADI H. and ROLAND M.: Quality of primary health care in Saudi Arabia: a comprehensive review International Journal for Quality in Health Care, 17 (4): 331-346, 2005.

12- BAYKAN Z., NAÇAR M., ÖZDEMIR S.B., POYRAZOGLU S. and ÇETINKAYA F.: Knowledge and attitude of family physicians regarding adult vaccination. World Journal of Vaccines, 1: 92-97, 2011.

13-Malaysian Society for Infectious disease and chemotherapy, Ministry of Health Malaysia. Adult Vaccination, 2003.

14- Aseer Directorate of Health, Personal Communication, 2017.

15-TAN T.Q., BHATTACHARYA L. and RBIE M.V.: Awareness, perceptions and knowledge of recommended adult vaccines among a nationwide sample of adult primary care providers. J. Reprod. Med. Jul-Aug., 56 (7-8): 3017, 2011.

16- HURLEY L.P., BRIDGES C.B., HARPAZ R., ALLISON M.A., O' LEARY S.T., CRANE L.A., BRTNIKOVA M., STOKLEY S., BEATY B.L., JIMENEZ-ZAMBRANO A. and KEMPE A.: Physician Attitudes Toward Adult Vaccines and Other Preventive Practices, United States, 2012. Public Health Reports, 131: 320-330, 2016.

17- Advisory Committee on Immunization Practices. Recommended Immunization Schedule for Children and Adolescents, United States, 2019. Accessed at www.cdc.gov/ vaccines/schedules/hcp/child -adolescent. html on $20 \mathrm{July}$, 2019.

18- MACDOUGALL D.M., HALPERIN N.A., MACKINNON-CAMERON D., MCNEIL S.A., LANGLEY J.M. and HALPERIN S.A.: The challenge of vaccinating adults: Attitudes and beliefs of the Canadian public and healthcare providers. BMJ. Open, 5: e009062, 2015.

19- PICKERING L.K., BAKER C.J., FREED G.L., GALL S.A., GROGG S.E., POLAND G.A., RODEWALD L.E., SCHAFFNER W., STINCHFIELD P., TAN L, ZIMMERMAN P.K. and OREN-STEIN W.A.: Immunization Programs for Infants, Children, Adolescents, and Adults: Clinical Practice Guidelines by the Infectious Diseases Society of America. Clinical Infectious Diseases, 49: 817840, 2009.

20- CARMAN W.F., ELDER A.G., WALLACE L.A., MCAULAY K., WALKER A., MURRAY G.D. and STOTT D.J.: Effects of Influenza Vaccination of Healthcare Personnel on Mortality Controlled Trial. Lancet, 355 (9198): 93-97, 2000.

21- POLAND G.A., TOSH P. and JACOBSON R.M.: Requiring Influenza Vaccination for Health Care Workers: Seven Truths We Must Accept. Vaccine, 23: 2251-2255, 2005.
22- HAYWARD A.C., HARLING R., WETTEN S., JOHNSON A.M., MUNRO S., SMEDLEY J., MURAD S. and WATSON J.M.: Effectiveness of an Influenza Vaccine Programme for Care Home Staff to Prevent Death, Morbidity, and Health Service Use among Residents: Cluster Randomised Con-trolled Trial. British Medical Journal, 333: 1241-1244, 2006.

23- SZUCS T.D., RUEF C., MÜLLER D., SOKOLOVIC E., BEELER I. and OSTERMAYER W.: The Economic Impact of Influenza in a University Hospital Setting. Infection Control \& Hospital Epidemiology, 22 (8): 472474, 2001.

24- MURRAY S.B. and SKULL S.A.: Poor Health Care Workers Vaccination Coverage and Knowledge of Vaccination Recommendations in a Tertiary Australian Hospital. Australian and New Zealand Journal of Public Health, 26 (1): 65-68, 2002.

25- ESPOSITO S., BOSIS S., PELUCCHI C., TREMOLATI E., SABATINI C., SEMINO M., MARCHISIO P., DELLA CROCE F. and PRINCIPI N.: Influenza Vaccination among Healthcare Workers in a Multidisciplinary University Hospital in Italy. BMC Public Health, 8: $422-$ 432, 2008.

26- AKA F. and DÜNDAR V.: Knowledge and Attitude for Transmission Risk of Hepatitis B and HIV and Universal Precautions in Health Care Workers. Klimik Journal, 8 (3): 114-119, 1995.

27- DEMIR I., KAYA S., DEMIRCI M. and ARıDOG AN B.: Investigation of Seropositivity of Hepatitis B Virus in Health-care Workers in Isparta, Türkiye. Turkish Journal of Infection, 20 (3): 183-187, 2006.

28- UZUN E, AKÇAM F., ZENGIN E., KIS IOĞLU A.N. and. AYAYLI G.: Evaluation of the Hepatitis B Infection Status, Knowledge and Behaviours of the Research Assistants of SDU School of Medicine. SDU School of Medicine, 5 (1): 22-27, 2008.

29- DENIS F., AGABEYTOL V. and AUFRERE A.: Evaluation of Strategy and Coverage Rates for Hepatitis B Vaccination in France, a Country with Low Endemicity. Médecine et Maladies Infectieuses, 34 (4): 149-158, 2004.

30- SIMARD E.P., MILLER J.T., GEORGE P.A., WASLEY A., ALTER M.J., BELL B.P. and FELLINI L.: Hepatitis B Vaccination Coverage Levels among Health Care Workers in the United States, 2002-2003. Infection Control \& Hospital Epidemiology, 28: 783-790, 2007.

31 -CAMPOS-OUTCALT D., JEFFCOTT-PERA M., CARTER-SMITH P., SCHOOF B.K. and YOUNG H.F.: Vaccines Provided by Family Physicians. Annals of Family Medicine, 8 (6): 507-510, 2010.

32- MÜLER D. and SZUCS T.D.: Influenza Vaccination Coverage Rates in 5 European Countries: A PopulationBased Cross - Sectional Analysis of the Seasons 02/03, 03/04 and 04/05. Infection, 35 (5): 308-319, 2007.

33- BLANK P.R., SCHWENKGLENKS M. and SZUCS T.D.: Influenza Vaccination Coverage Rates in Five European Countries during Season 2006/07 and Trends over Six Consecutive Seasons. BMC Public Health, 8 (271): 1-13, 2008. 
34- JOHNSON D.R., NICHOL K.L. and LIPCZYNSKI K.:

Barriers to Adult Immunization. American Journal of Medicine, 121 (7): 28-35, 2008.
35- National Foundation for Infectious Diseases. Call to Action: Adult Vaccination Saves Lives. Bethesda, MD, 2012.

\section{معرفة واتجاهات وممارسات أطباء الرعاية الصحية الأولية

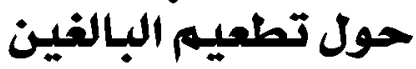 بمدينة أبها، المملكة العربية السعودين البين}

هدف الدراسة: تقييم معرفة واتجاهات وممارسات الأطباء مقدمى الرعاية الصحية الأولية، فيما يتعلق بتطعيم اللبالغين وتفطية التطعيمات الخاصة بهم، وكذلك استكشاف الأسباب المحتملة المؤدية لانخفاض تلفياه تغطية التطعيم.

المنهجية: بعد اتباع نسق دراسة بحثية مستعرض، تضمنت هذه الدراسة ب ـا طبيب رعاية صحية أولية بمديذة أبها ، واستنادًا على دراسة مماثلة سابقة، فقد تم استخدام استبيان لجمع استبيان لجمع البيانات ذاتيا.

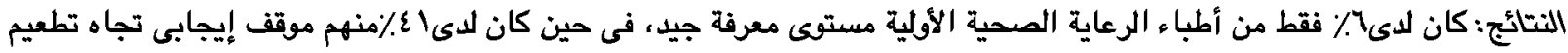

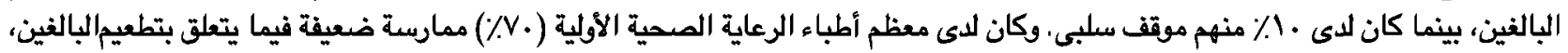

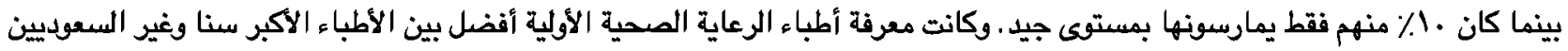

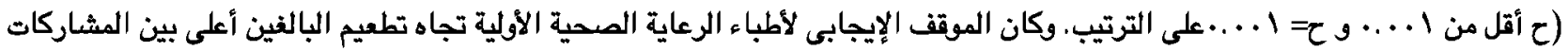

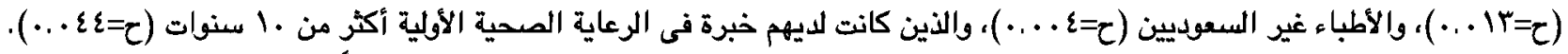

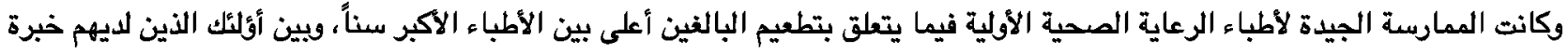

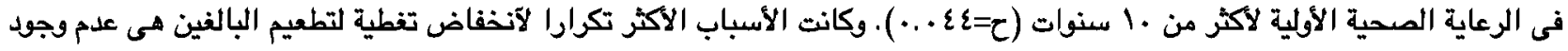

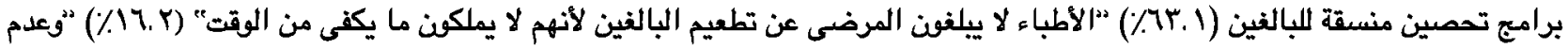

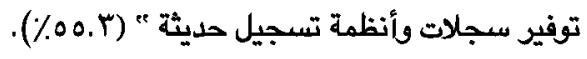

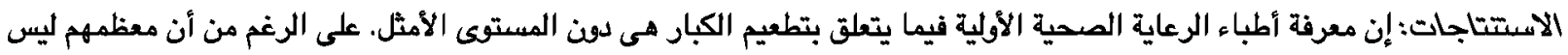

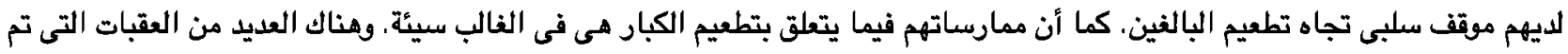
التعرف عليها فى هذه الدراسة تقاهل من ممارسة تطعيم البالفين كمان مارساتين.

التوصيات: يجب تصميم مبادىء توجيهية لتطعيم الكبار، كما ينبغى تنظيم دودات التعليم الطبى المستمر لأطباء الرعاية الصحية الأولية

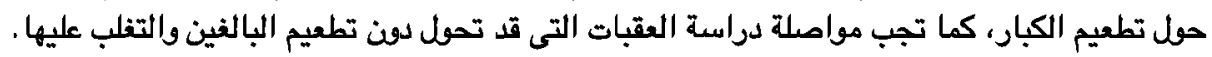

